NEGOSIASI KEPENTINGAN DALAM PERUMUSAN RPJMD DIY 2017-2022 DALAM KERANGKA ADVOCACY COALITION FRAMEWORK

\title{
NEGOTIATION OF INTEREST IN RPJMD DIY 2017-2022 POLICY FORMULATION USING ADVOCACY COALITION FRAMEWORK
}

\author{
Anggalih Bayu Muh. Kamim¹, Ichlasul Amal', M. Rusmul Khandiq ${ }^{3}$
}

Departemen Politik \& Pemerintahan, FISIPOL, Universitas Gadjah Mada ${ }^{1}$

JI. Sosio-Justisia, Caturtunggal, Depok, Sleman, DI Yogyakarta.

Departemen Pembangunan Sosial \& Kesejahteraan, FISIPOL, Universitas Gadjah Mada $^{2}$

JI. Sosio-Justisia, Caturtunggal, Depok, Sleman, DI Yogyakarta.

Departemen IImu Komunikasi, FISIPOL, Universitas Gadjah Mada ${ }^{3}$

Jl. Sosio-Justisia, Caturtunggal, Depok, Sleman, DI Yogyakarta.

Email: anggalih.bayu@yahoo.co.id; ichlamal14@gmail.com;

m.r.khandiq@gmail.com

Naskah diterima: 28 November 2018; revisi terakhir: 26 Februari 2019; disetujui: 26 Maret 2019

How to Cite: Kamim, Anggalih B.M., Amal, Ichlasul., dan Khandiq, M. Rusmul. (2019). Negoisasi Kepentingan dalam Perumusan RPJMD DIY 2017-2022 dalam Kerangka Advocacy Coalition Framework. Jurnal Borneo Administrator, 15 (1), 81-98. https://doi.org/10.24258/jba.v15i1.404

\section{Abstract}

An exploration of policy changes and learning and interest negotiation in formulating policy are useful for mapping the process of compromising between the authorities and citizens. The study aims to explore the relations of external actors and local governments as a reflection of the state in the formulation of 2017-2022 DIY development planning policies to ensure no policies that favor the interests of certain groups. This research was conducted in qualitative research methods. This research was framed by a case study method. The research was conducted in agencies/ companies/ academics/donor institutions/ parliament and the community involved and affected in the process of formulating DIY development planning policies. Research showed that there were some disadvantages of ACF model. The first disadvantage related to the inability of the ACF to explain the position of one of the "plural-faced" parties. The next disadvantage was the fact that ACF could not explain in detail the exact reason behind the formation of a coalition. The last disadvantage was that the ACF could not explain the dispersal of movements in a coalition.

Keywords: RPJMD DIY 2017-2022, Advocacy Coalition Framework, Policy Coalition 


\begin{abstract}
Abstrak
Penggalian policy change and learning serta negosiasi kepentingan dalam perumusan kebijakan berguna untuk memetakan proses kompromi penguasa dan warga. Studi untuk menggali dan mendalami relasi aktor eksternal dan pemerintah daerah sebagai cerminan negara dalam perumusan kebijakan perencanaan pembangunan DIY 20172022 menjadi penting untuk memastikan tidak adanya kebijakan yang berpihak pada kepentingan kalangan tertentu. Penelitian ini dilakukan dengan metode penelitian kualitatif. Penelitian ini dibingkai dengan metode studi kasus. Penelitian dilakukan di instansi/perusahaan/kalangan akademisi/lembaga donor/parlemen serta kalangan masyarakat yang terlibat dan terdampak dalam proses perumusan kebijakan perencanaan pembangunan DIY. Penelitian menunjukan bahwa dalam model ACF terdapat beberapa kekurangan. Kekurangan pertama berkaitan dengan ketidakmampuan ACF untuk menjelaskan posisi salah satu pihak yang "berwajah majemuk". Kekurangan berikutnya adalah ACF tidak dapat menjelaskan dengan detail alasan terbentuknya sebuah koalisi secara pasti. Kekurangan terakhir yaitu ACF tidak dapat menjelaskan terpencarnya gerakan dalam suatu koalisi.
\end{abstract}

\title{
Kata Kunci : RPJMD DIY 2017-2022, Advocacy Coalition Framework, Koalisi Kebijakan
}

\section{A. PENDAHULUAN}

Studi ini akan menggali mengenai negosiasi kepentingan dalam proses perumusan kebijakan publik, khususnya perencanaan pembangunan daerah di Daerah Istimewa Yogyakarta yang mengangkat visi baru "Menyongsong Abad Samudera Hindia" pada tahun 2017-2022. Pendalaman terhadap negosiasi dalam proses perumusan kebijakan RPJMD DIY 2017-2022 menjadi penting untuk melihat terbentuknya consensus building yang mempertemukan berbagai kepentingan aktor. RPJMD yang pada dasarnya digunakan sebagai acuan untuk melaksanakan pembangunan daerah dalam jangka waktu lima tahun serta menerjemahkan janji politik kepala daerah setelah dilantik penting untuk dipetakan proses kompromi yang muncul antaraktor. Penelitian dibingkai dengan sudut pandang Advocacy Coalition Framework (ACF) untuk melihat proses perubahan kebijakan, pembentukan kebijakan serta pendalaman terhadap negosiasi yang muncul dipengaruhi oleh faktor internal dan faktor eksternal dari koalisi aktor yang muncul dalam perumusan kebijakan. Studi ini akan menggali mengenai negosiasi kepentingan dalam proses perumusan kebijakan publik, khususnya perencanaan pembangunan daerah di Daerah Istimewa Yogyakarta yang mengangkat visi baru "Menyongsong Abad Samudera Hindia" pada tahun 2017-2022. RPJMD DIY 2017-2022 sendiri menjadi kelanjutan dari pelaksanaan RPJMD DIY 2012-2017 yang mulai fokus untuk mengembangkan wilayah selatan DIY. Fokus pemerintah untuk mengembangkan sektor maritim pada khususnya menjadi strategi yang diambil untuk melaksanakan pembangunan wilayah selatan DIY. RPJMD DIY 2017-2022 sendiri setelah ditetapkan memiliki beberapa isu penting yakni, kemiskinan, ketimpangan wilayah, pembiayaan di luar APBD, dan penyiapan sarana penunjang Bandara NYIA. Pengkajian akan dilakukan untuk memperdalam bagaimana interaksi para aktor, strategi dan peta kepentingan dalam memengaruhi consensus building untuk memperjuangkan kepentingannya, agar diwujudkan menjadi sebuah kebijakan publik.

Studi ini berusaha melihat di luar mainstream pengkajian kebijakan perencanaan pembangunan daerah yang menggunakan sudut pandang teknokratis, administratif dan institusional (Afriko, 2013; Nursini, 2010; Puspita, 2016; Syaifullah, 2007). Pengkajian 
negosiasi kepentingan dalam kebijakan perencanaan pembangunan daerah jarang dilakukan dan dapat mendorong kebaharuan dalam pendalaman studi sekaligus mengevaluasi proses kompromi yang muncul dengan pihak-pihak di luar negara untuk mengintervensi arah pembangunan daerah (Iskandar, 2012; Soares, Nurpratiwi, \& Makmur, 2015; Tompo, Kadir, \& Mufhi, 2012).

Dugaan negosiasi kepentingan antara pemerintah daerah dan aktor lain dalam penyusunan perencanaan pembangunan DIY 2017-2022 terlihat dari latar belakang kebijakan yang melibatkan banyak kepentingan. Kemungkinan adanya tarik-menarik kepentingan antara pemerintah daerah dengan aktor lain dalam perencanaan pembangunan di DIY juga digali dengan melihat strategi untuk mencapai visi yang telah diambil. Ada beberapa strategi yang akan ditempuh untuk memaksimalkan potensi Samudra Hindia sekaligus untuk mengentaskan kemiskinan, antara lain : aktif mengisi kesepakatan Indian Ocean Rim Association (IORA) di bidang perikanan, energi kelautan, pelabuhan dan pelayaran, teknologi kelautan, mineral bawah laut, dan pariwisata; melakukan silang ruang wilayah, dalam artian menjalin kerja sama dengan kabupaten-kabupaten di Selatan Pulau Jawa; dan melakukan silang birokrasi. Pemerintah daerah juga akan mengambil strategi dengan pendekatan multidisiplin ilmu untuk mengubah budaya kontinental masyarakat menjadi budaya maritim (Deni, 2017).

Kacamata ACF yang digunakan untuk melihat perumusan kebijakan RPJMD DIY 2017-2022 menjadi menarik untuk memahami proses negosiasi kepentingan yang terjadi dalam setting kepala daerah yang juga menjalankan banyak peran. Posisi Gubernur DIY sebagai Sultan Kasultanan Ngayogyakarta Hadiningrat, wakil pemerintah pusat di daerah serta kepala daerah otonom sekaligus akan memengaruhi faktor internal dan eksternal perumusan kebijakan. Faktor keistimewaan posisi Gubernur DIY ini menjadi menarik karena berbeda dengan kasus-kasus di daerah lain, seperti di Mojokerto, di mana antar stakeholder memiliki posisi yang setara baik secara struktural maupun kultural, sehingga penyelesaian konflik kepentingan yang ada karena adanya kesepakatan kepentingan dengan kesamaan kekuatan yang dimiliki oleh semua pihak yang terlibat (Esa, 2016). Atau penelitian-penelitian lain yang juga berfokus pada RPJMD dengan kerangka berbeda seperti kerangka hukum maupun good governance (Purnama, 2013; Padang \& Kusmanto, 2015). Perbedaan lainnya terdapat pada penggunaan sudut pandang ini di mana ACF biasanya digunakan untuk melihat proses kebijakan dalam rentang waktu setidaknya satu dekade (Ainuson, 2009; Babon, 2016; Clark, 2018; Howlett, 2016). Dalam penelitian ini, proses kebijakan yang dilihat terbatas pada perencanaan pembangunan DIY semenjak tahun 2012-2017. RPJMD DIY 2012-2017 menjadi titik tolak penting dalam perubahan kebijakan di DIY karena mulai mendorong pengembangan sektor maritim sebagai fokus pembangunan, di mana RPJMD sebelumnya belum mulai mengarah ke sana. RPJMD DIY 2017-2022 tentunya akan dipengaruhi oleh kebijakan sebelumnya tersebut serta dapat menggali kelemahan yang mungkin muncul dari penggunaan ACF dalam memahami proses negosiasi kepentingan serta membentuk kesepahaman bersama mengenai kepentingan bersama tiap koalisi aktor.

\section{B. METODE PENELITIAN}

Penelitian ini dilakukan dengan metode penelitian kualitatif. Penelitian dibingkai dengan metode studi kasus. Penelitian dilakukan terhadap instansi pemerintah yang terdiri atas Badan Perencanaan Pembangunan Daerah (BAPPEDA) DIY, Badan Koordinasi Penanaman Modal (BKPM) Kantor Wilayah DIY, Dinas Kelautan dan Perikanan DIY, Fraksi PKS DPRD DIY, Fraksi PAN DPRD DIY, Komisi A DPRD DIY serta Dinas 
Perhubungan DIY, Dinas Perindustrian dan Perdagangan DIY; lembaga swadaya masyarakat seperti Institute Research and Empowerment (IRE) dan IDEA (Institute for Development and Economic Analysist), Wahana Lingkungan Hidup (Walhi) Yogyakarta; kalangan akademisi yang tergabung dalam tim perancang RPJMD DIY 2017-2022. Pengumpulan data dilakukan dengan quasi partisipant observation dengan melakukan penelusuran di sepanjang pantai Kabupaten Bantul- Pantai Glagah, Kabupaten Kulon Progo pada 14-15 Juli 2018 serta di wilayah Kabupaten Gunungkidul terhadap Pantai Baron, Pantai Watu Kodok, Pantai Drini, Pantai Sundak dan Pantai Sadeng pada 16-17 Agustus 2018. Wawancara mendalam, penelusuran dokumen juga dilakukan terhadap studi-studi pendahuluan yang dibuat dalam mendukung perumusan kebijakan perencanaan pembangunan DIY "Menyongsong Abad Samudera Hindia" 2017-2022 serta naskah akademik, policy paper yang digunakan untuk mendukung perumusan kebijakan. Analisis data yang dilakukan meliputi proses reduksi data, penyajian data, verifikasi dan penarikan kesimpulan.

\section{KERANGKA TEORI}

Salah satu kerangka ditawarkan oleh ilmuwan kebijakan, Paul A. Sabatier menciptakan model analisis mengenai proses kerja pembuatan kebijakan untuk menyelesaikan permasalahan publik yang melibatkan banyak aktor dan banyak kepentingan. Model ini bermaksud untuk menjelaskan kepercayaan dan perubahan kebijakan, apabila ada ketidaksepakatan dan perdebatan teknis yang melibatkan banyak aktor. Aktor seperti pemerintah, kelompok kepentingan, institusi penelitian, pihak swasta digambarkan akan terlibat proses perumusan kebijakan. Advocacy Coalition Framework (ACF) menjadi salah satu kerangka yang berguna menganalisis kebijakan publik dengan melihat proses tarik-menarik kepentingan dalam perumusan kebijakan (Weible \& Sabatier, 2007).

ACF digambarkan sebagai sebuah "struktur pembuatan kebijakan" yang terdiri atas beberapa komponen yaitu: parameter yang relatif stabil, subsistem kebijakan (di mana di sinilah proses pembuatan kebijakan terjadi), dan peristiwa-peristiwa eksternal di luar sistem. Subsistem kebijakan memiliki beberapa komponen seperti sistem kepercayaan, koalisi advokasi, policy broker, sumber daya, venues, dan mekanisme perubahan kebijakan (Weible \& Sabatier, 2007).

Parameter yang relatif stabil adalah seperangkat parameter yang cenderung tetap, biasanya berusia 100 tahun lebih dan memengaruhi bagaimana kebijakan atas suatu tempat. Parameter ini terdiri dari empat aspek yaitu karakteristik dasar dari wilayah yang dipermasalahkan, persebaran sumber daya alam di wilayah tersebut, nilai sosio-kultural dan struktur sosial dari wilayah tersebut, serta peraturan hukum dasar dari wilayah tersebut. Aspek-aspek ini menjadi dasar dalam memahami seperti apa permasalahan yang ada di wilayah di mana kebijakan tersebut akan dibuat (Weible \& Sabatier, 2007).

Subsistem kebijakan adalah bagian dari sistem besar pembuatan kebijakan yang terbentuk dari pemahaman terhadap parameter-parameter yang relatif stabil oleh berbagai aktor. Subsistem ini melibatkan berbagai level pemerintahan, isu-isu yang diperjuangkan (seperti kelompok pro pembangunan atau kalangan konservatif), dan ratusan partisipan kebijakan dari beragam latar belakang dan posisi mulai dari pemerintah pusat, pemerintah daerah, kalangan bisnis, peneliti, kelompok kepentingan, dan media (Weible \& Sabatier, 2007).

Salah satu komponen yang cukup menarik dari subsitem kebijakan adalah policy broker. Policy broker secara sederhana dapat diartikan sebagai aktor yang berperan dalam 
memediasi konflik yang timbul dari perbedaan kepentingan berbagai koalisi kebijakan. Tiap koalisi advokasi pasti membawa kepentingan yang berbeda, dan konflik antar koalisi dapat berujung pada kondisi stalemate mendorong tidak adanya kebijakan yang dihasilkan. Policy broker bergerak sebagai aktor yang dipercaya oleh kedua belah pihak untuk menemukan titik kompromi paling rasional dan dapat diterima. Policy broker dapat berupa anggota parlemen terpilih, pegawai negeri yang memiliki kekuasaan tinggi, dan pengadilan (Weible \& Sabatier, 2007).

Komponen terakhir yaitu peristiwa-peristiwa di luar sistem. Terkadang dalam proses pembuatan kebijakan ada beberapa peristiwa yang berada di luar proses tersebut yang dapat memengaruhi perubahan keyakinan dan kebijakan yang dibuat. Weible dan Sabatier sendiri menyebutkan ada empat hal yang dapat memengaruhi yaitu perubahan sosioekonomi besar-besaran, perubahan opini publik, perubahan koalisi dalam pemerintahan, dan pilihan kebijakan dan pengaruh dari subsistem di luar sistem pembuatan kebijakan tersebut. Ada beberapa komponen lain yang dapat dibuat untuk mendorong perubahan kebijakan yaitu kondisi stalemate menyakitkan bagi salah satu pihak, kejutan dari luar seperti perubahan drastis dalam kondisi sosio-ekonomi di negara tersebut, dan akumulasi dari hasil penelitian akademisi terhadap masalah publik dalam perumusan kebijakan tersebut (Weible \& Sabatier, 2007).

Teori ACF dianggap lebih komprehensif dalam mengkaji mengenai proses pembuatan kebijakan dibandingkan teori yang biasa digunakan dalam studi kebijakan yaitu Stages Heuristic. Stages Heuristic merupakan teori yang menawarkan cara penelaahan proses pembuatan kebijakan dengan melihatnya dalam beberapa tahap yang bersifat saling berkaitan, berurutan, dan sirkular (Kulac \& Ozgur, 2017). Stages Heuristic memiliki banyak keunggulan seperti dapat membuat penelaahan terhadap proses pembuatan kebijakan semakin rinci dan sistematis. Teori ini banyak ditentang terutama oleh Sabatier dan kemudian mengajukan ACF sebagai model analisis alternatif. Stages Heuristic dikritik, karena tidak terlalu memperhatikan hubungan sebab akibat proses pembuatan kebijakan, tidak memberikan dasar yang jelas dalam penelitian empiris terhadap studi proses kebijakan, kurang akurat dalam mendeskripsikan kenyataan dalam prosesnya, dan terlalu bersifat top-down (Jenkin-Smith \& Sabatier, 1994). Sabatier sendiri mengajukan ACF dengan basis kritiknya terhadap Stages Heuristic terutama di bagian top-down dengan mengkombinasikan analisis top-down dan bottom-up sekaligus, lalu mendudukkan aktoraktor di luar pemerintah sebagai bagian dari subsistem pembuatan kebijakan, peran waktu dan aspek kepercayaan yang berada dalam level individu sebagai faktor determinan dalam penentuan kebijakan.

Sudut pandang ACF seharusnya digunakan untuk melihat policy change and policy learning minimal pada jangka waktu pada satu dekade, maka kajian ini membatasi penggunaan ACF pada periode pelaksanaan RPJMD DIY 2012-2017 yang menjadi titik penting perubahan arah pembangunan DIY sampai proses perumusan kebijakan RPJMD DIY 2017-2022. Faktor eksternal yang terdiri atas relatively stable parameters seperti kondisi geografis, kondisi budaya, pembagian sumber daya, regulasi serta nilai-nilai setempat. Serta external event seperti perubahan kondisi sosial-ekonomi, perubahan kebijakan yang mengikuti serta opini publik dianggap berpengaruh terhadap proses tarikmenarik kepentingan antaraktor dalam perumusan RPJMD DIY 2017-2022. Kondisi internal, yakni kondisi masing-masing aktor yang diasumsikan akan saling membentuk koalisi demi memperjuangkan kepentingan masing-masing, menjadi penting untuk dilihat strategi yang digunakannya. Usaha policy broker untuk mempertemukan kepentingan aktor penting juga harus didalami terhadap proses consensus building yang muncul. 


\section{HASIL DAN PEMBAHASAN}

Tabel 1.

Penyusunan RPJMD DIY 2017-2022 Dilihat dari Kacamata Pendekatan Penyusunan

\begin{tabular}{ll}
\hline Pendekatan Perencanaan & \multicolumn{2}{c}{ Bentuk } \\
\hline Politik & Janji politik Gubernur DIY Sultan HB X dengan visi \\
& "Menyongsong Abad Samudera Hindia."
\end{tabular}

Teknokratik

Pembuatan dokumen perencanaan pembangunan jangka menengah daerah oleh Bappeda dan satuan Organisasi Pemerintah Daerah (OPD).

Partisipatif Bappeda DIY mengundang representasi masyarakat dalam musrenbang untuk menyelaraskan perancangan perencanaan pembangunan.

Atas-bawah Pembuatan prioritas kerja untuk menentukan strategi dan 86 indikator untuk mencapai visi-misi Gubernur DIY oleh tim anggaran Pemda DIY.

Bawah-atas Sinkronisasi melalui musyawarah yang dilaksanakan di tingkat nasional, provinsi, kabupaten/kota, kecamatan, dan desa.

Sumber: Diolah dari Data Primer

Penggunaan kerangka ACF mendorong peneliti melihat proses kebijakan sebagai kompetisi dan interaksi antar koalisi aktor. Koalisi ini bergerak berdasarkan sistem kepercayaan mereka, mengadvokasi definisi mereka tentang masalah kebijakan dan implementasi dari solusi yang mereka tawarkan. Koalisi adalah kelompok aktor dengan keyakinan serupa (termasuk kelompok kepentingan, aktor negara di berbagai tingkat pemerintahan, dan LSM) yang bertujuan untuk meyakinkan pembuat kebijakan untuk mengubah kebijakan. Persaingan dan interaksi koalisi berlangsung dalam subsistem kebijakan (Khayatzadeh-mahani, Breton, Ruckert, \& Labonte, 2018). Ada setidaknya tiga komponen yang menyusunnya, yaitu parameter yang relatif stabil, peristiwa-peristiwa di luar sistem, dan subsistem kebijakan itu sendiri (Weible \& Sabatier, 2007).

Kondisi geografis DIY menjadi salah satu bagian penting parameter yang relatif stabil dalam proses perubahan kebijakan. DIY tersusun dari satuan Pegunungan Selatan yang masuk ke dalam kawasan Pegunungan Seribu, dengan bentuk alam didominasi oleh perbukitan batu gamping yang kritis, tandus, dan kekurangan air. Bagian utara DIY terdapat satuan Gunung Merapi yang terbentang dari kerucut gunung api hingga dataran fluvial di lereng Merapi yang subur. Kawasan ini rentan terhadap erupsi dan gempa. Bagian tengah DIY terdapat Wonosari Basin yang memiliki karakter lapisan tanah dangkal berbahan dasar gamping dengan vegetasi penutup relatif jarang. Bagian barat terdapat Pegunungan Kulon Progo yang cenderung berbukit, sehingga cocok untuk perkebunan dan berlereng curam dengan potensi air tanah yang kecil dan mudah terjadi longsor. Serta daratan aluvial subur yang membentang di sepanjang daerah selatan DIY di antara Pegunungan Kulon Progo dan Pegunungan Selatan. Selain itu, ada beberapa bentang alam khusus seperti bentang alam Marine dan Aeolin di wilayah pantai selatan yang dapat digunakan sebagai tempat wisata (Gubernur Daerah Istimewa Yogyakarta, 2017; Pemerintah Daerah Istimewa Yogyakarta, 2018).

Daerah selatan DIY, yang menjadi salah satu fokus utama pembangunan di RPJMD DIY 2017-2022 memiliki potensi berupa sumber daya kelautan bernilai ekonomi penting, 
seperti di Glagah-Karangwuni, Baron, dan Sadeng. Sumber daya kelautan ini diperkirakan bernilai sampai Rp 715,085 milyar (Sahubawa, Khakim, \& Lasindrang, 2015). Selain itu, intensifikasi sektor perikanan di kawasan selatan DIY seperti di Pandansimo diperkirakan dapat meningkatkan pertumbuhan perekonomian di kawasan selatan terutama Kulon Progo dan Bantul dibandingkan sektor lain seperti perindustrian dan pertanian (Yuliadi, 2013). Namun, di daerah selatan, terutama di pesisir merupakan daerah yang rentan terhadap berbagai peristiwa alam seperti tsunami di pesisir timur, dan pendangkalan pantai serta abrasi besar di pesisi barat, serta gempa seismik (Cahyadi, Afianita, Gamayanti, \& Fauziyah, 2012; Mustafa \& Yudichara, 2007; Yudhicara, Yuningsih, Mustafa, Kristanto, \& Noviadi, 2003), kenaikan muka air laut (Hastuti, 2012), dan bentuk peristiwa alam lainnya yang bisa membahayakan. Selain itu, di kawasan tapak Bandara NYIA, terdapat potensi tsunami mulai dari tinggi hingga rendah, dengan risiko rata-rata sedang (Paripurna, Nugroho, Wicaksono, Pradhana, \& Nugroho, 2015). Hal ini menjadi salah satu sumber kontroversi mengenai kebijakan-kebijakan pembangunan yang ada di DIY, terutama pembangunan sesuai RPJMD DIY 2017-2022 yang fokus ke pantai selatan.

Masalah lain muncul berupa ketimpangan di DIY yang terus meningkat jika dilihat dari indeks ketimpangan wilayah yang mencapai 0,47 dalam RPJMD DIY 2012-2017, di mana targetnya adalah sekitar 0,45 , dan indeks ketimpangan pendapatan yang mencapai 0,43, di mana targetnya adalah 0,29 (Gubernur Daerah Istimewa Yogyakarta, 2017). Selain itu, walaupun IPM di DI Yogyakarta termasuk tinggi $(78,38)$, namun kesenjangan IPM yang ada juga cukup tinggi di mana jarak antara IPM tertinggi (Kota Yogyakarta, 85,32) dengan IPM terendah (Gunungkidul, 67,82) cukup jauh. Bahkan, IPM Gunungkidul berada di bawah rata-rata nasional $(70,18)$ (Pemerintah Daerah Istimewa Yogyakarta, 2018). Tingkat kemiskinan DIY selama 2012-2017, walaupun mengalami penurunan masih termasuk kategori tinggi secara nasional. Persentase angka kemiskinan di DIY tertinggi sePulau Jawa dan terendah ketiga secara nasional (Nadjib, 2017). Hal ini menyebabkan isu kemiskinan dan kesenjangan wilayah menjadi isu utama dalam perumusan RPJMD 20172022.

Selain itu, peraturan-peraturan yang berlaku juga menentukan perencanaan RPJMD DIY 2017-2022. Peraturan yang mendasari pembentukan RPJMD secara umum adalah UU No. 23 Tahun 2014 tentang Pemerintahan Daerah, UU No. 25 Tahun 2004 tentang Sistem Perencanaan Pembangunan Nasional, PP No. 8 Tahun 2008, dan Permendagri No. 86 Tahun 2017. Ada beberapa dokumen yang berkaitan dengan RPJMD DIY 2017-2022, yaitu UU No. 13 Tahun 2012 tentang Keistimewaan DI Yogyakarta, UU No. 5 Tahun 1960 tentang Pokok-Pokok Agraria, Perdais DIY No. 1 Tahun 2017 tentang Pengelolaan dan Pemanfaatan Tanah Kasultanan \& Tanah Kadipaten, Perdais DIY No. 2 Tahun 2017 tentang Tata Ruang Tanah Kasultanan dan Tanah Kadipaten, Perdais DIY No. 1 Tahun 2018 tentang Kelembagaan Pemerintah Daerah Daerah Istimewa Yogyakarta, Perda No. 2 Tahun 2010 tentang Rencana Tata Ruang Wilayah Provinsi DIY (yang hingga 2018 masih proses peninjauan), dan Laporan Keterangan Pertanggungjawaban Akhir Masa Jabatan Gubernur DIY 2012-2017. Salah satu peraturan yang cukup memengaruhi penyusunan RPJMD DIY 2017-2022 ini adalah UU No. 13 Tahun 2012 dan UU No. 5 Tahun 1960. UU No. 13 Tahun 2012 yang mengatur tidak hanya masalah keistimewaan DI Yogyakarta secara budaya saja, namun juga secara politik dan, terkhusus, dalam urusan tata ruang. Masalah munculnya Sultan Ground dan Pakualaman Ground yang didasarkan pada Rijksbald Kasultanan No. 16 Tahun 1918 (tanah swapraja) bertentangan dengan UU No. 5 Tahun 1960 yang menghapuskan status tanah swapraja maupun bekas swapraja. Beberapa pembangunan, termasuk proyek bandara NYIA yang merupakan salah satu isu utama 
dalam RPJMD DIY 2017-2022, menggunakan tanah Pakualaman Ground ini, yang sebelumnya dihapuskan menurut UU No. 5 Tahun 1960. Kerancuan ini menyebabkan protes di Kulon Progo, di mana bandara tersebut akan didirikan. Sehingga penyusunan RPJMD, yang memasukkan NYIA, mendapatkan pertentangan (Hasim, 2016; Somad, 2016). Walaupun, seperti yang akan dijelaskan selanjutnya, penyusunan RPJMD DIY lebih bersifat top-down sehingga protes masyarakat semacam ini tidak terakomodasi dengan baik.

Pembahasan external events dalam studi kasus perumusan kebijakan RPJMD DIY 2017-2022, pertama dilihat dari perubahan kondisi sosial ekonomi. Perubahan ini dapat memengaruhi subsistem secara substansial, baik dengan melihat asumsi kausalitas kebijakan saat ini atau dengan secara signifikan mengubah dukungan politik dari berbagai koalisi advokasi. Visi Gubernur DIY periode 2017-2022 dengan tema "Menyongsong Abad Samudera Hindia untuk Kemuliaan Martabat Manusia Jogja" sebagai lanjutan dari visi Gubernur DIY tentang “Among Tani Dagang Layar" pada 2012-2017 memperlihatkan kecenderungan pembangunan wilayah selatan sebagai basis untuk meningkatkan kesejahteraan masyarakat serta mengurangi angka kemiskinan. Bappeda sebagai aktor strategis perencanaan pembangunan di DIY fokus pada pertumbuhan perekonomian wilayah melalui pengembangan sektor-sektor unggul khususnya pengembangan sektor perdagangan dan jasa berguna mendukung sektor strategis pembangunan pariwisata DIY yang diyakini dapat memberikan multiplier effect pada sektor lainnya.

Dampak dari meningkatnya pertumbuhan penduduk, arus pendatang yang begitu besar, dan kecenderungan kebijakan berorientasi pada industri pariwisata tentu akan berpengaruh terhadap permintaan lahan. Oleh karena itu, tidak ada pilihan lain untuk tidak mengkonversi lahan, demi mencukupi kebutuhan akan perumahan dan sarana penunjang pariwisata. Penelitian yang dilakukan oleh Prihatin (2016) menunjukan dalam beberapa tahun terakhir, laju pertumbuhan Produk Domestik Regional Bruto (PDRB) dari sektor pertanian di DIY mengalami penurunan pertumbuhan. Pada tahun 2010, sektor pertanian menyumbang PDRB sebesar Rp. 3,63 triliun, lalu pada tahun 2011 angkanya menurun 2,12 persen menjadi Rp 3,55 triliun (Prihatin, 2016). Secara persentase pun, sektor pertanian terus mengalami penurunan. Dari data BPS DIY, pada 2011, sektor ini menyumbang 10,94\% dari total PDRB, dan terus menurun ke 10,52\% pada 2014 dan terakhir ke 9,78\% pada 2018. (Badan Pusat Statistik, 2018). Pelan tapi pasti, kebijakan yang cenderung pada sektor maritim akan meminggirkan sektor pertanian di DIY yang pelan-pelan mulai ditinggalkan oleh penduduknya.

Perubahan selanjutnya terlihat dari sistematika koalisi pemerintahan dari kebijakan maupun program nasional yang turut andil dalam pembentukan kebijakan di DIY. Bappeda DIY dalam laporan rancangan akhir RPJMD DIY memberikan penjelasan bahwa penyusunan RPJMD DIY 2017-2022 berpedoman pada RPJM Nasional 2015-2019 (Pemerintah Daerah Istimewa Yogyakarta, 2018). Salah satu program yang berkorelasi dengan arah pembangunan DIY terlihat pada poin pertama RJMN 2015-2019 yakni "Menghadirkan Kembali Negara untuk Melindungi Segenap Bangsa dan Memberikan Rasa Aman Pada Seluruh Warga Negara, Melalui Politik Luar Negeri Bebas Aktif, Keamanan Nasional yang Terpercaya dan Pembangunan Pertahanan Negara Tri Matra Terpadu yang Dilandasi Kepentingan Nasional dan Memperkuat Jati Diri Sebagai Negara Maritim" (Wedhaswary, 2014). Bappeda menambahkan bahwa kebijakan maritim yang direncanakan oleh Pemda DIY didasari oleh posisi wilayah yang strategis dan berpotensi meraih keuntungan dengan adanya Kra Canal dan IORA (Indian Ocean Rim Association) asosiasi negara-negara yang ada di Samudera Hindia. Periode 2017-2022, Pemda DIY 
menginginkan menjadi pemain di sektor maritim (Hasil wawancara dengan staf dan Kabid Perencanaan Bappeda DIY pada 26 April 2018).

Perubahan eksternal terakhir mengenai keputusan kebijakan dan dampaknya yang menjadi elemen dinamis dalam subsistem. Peranan pemerintah pusat dan daerah dilihat oleh Bappenas untuk mendorong produktivitas dan peningkatan aktivitas sektor swasta dengan mempertimbangkan fokus wilayah pada kawasan-kawasan yang memiliki daya ungkit (leverage) yang besar untuk dikembangkan seperti Kawasan Industri, Kawasan Ekonomi Khusus (KEK), Kawasan Pariwisata (Sambutan Kepala Bappenas dalam acara Musrenbang RKPD DIY pada 15 Maret 2017). Borobudur sebagai salah satu bagian dari Kawasan Strategis Pariwisata Nasional (KSPN) akan disokong oleh project strategis NYIA, sehingga memungkinkan sinergitas antardaerah dari tata kelola pemerintahan, perencanaan, sampai ke penganggaran kemudian pengendalian dengan Provinsi Jawa Tengah (Hasil wawancara dengan staf dan Kabid Perencanaan Bappeda DIY pada 26 April 2018).

Komponen terakhir dalam kasus perumusan kebijakan RPJMD DIY 2017-2022, policy subsystem yang ada setidaknya melibatkan dua koalisi dalam perjuangan kebijakan yakni koalisi penguasa dan koalisi masyarakat sipil. Koalisi penguasa terdiri atas Gubernur DIY, OPD (Organisasi Perangkat Daerah), DPRD DIY, Badan Hukum Khusus Kasultanan, Badan Hukum Khusus Pakualaman serta pihak perusahaan. Koalisi masyarakat sipil terdiri atas kalangan lembaga swadaya masyarakat yang aktif membantu warga di akar rumput. Kedua koalisi sebenarnya dipersatukan oleh kepentingan yang sama, yakni ingin mengadakan perbaikan kesejahteraan di provinsi Daerah Istimewa Yogyakarta. Koalisi penguasa datang dengan pilihan kebijakan bahwa pengembangan wilayah selatan DIY terutama pada sektor maritim sebagai solusi untuk perbaikan kesejahteraan. Koalisi masyarakat sipil hadir dengan pilihan kebijakan bahwa pembangunan sebagai upaya perbaikan kesejahteraan seharusnya dilakukan dengan melihat potensi, kebutuhan riil, kapasitas dan partisipasi warga, agar tidak semata menjadi objek pembangunan.

Gubernur DIY sebagai aktor utama dalam koalisi penguasa menjadi penggerak proses advokasi yang dilakukan oleh koalisi. RPJMD yang sejatinya adalah bentuk penerjemahan dari janji politik Gubernur DIY setelah dilantik menyebabkan koalisi penguasa memiliki sumber daya dan sistem kepercayaan yang relatif kuat. Posisi Gubernur DIY yang juga berkedudukan sebagai raja dari sebuah institusi Kasultanan dan tidak dipilih melalui pemilihan umum juga mendorong dapat memanfaatkan sumber daya simbolik berupa "ketundukan pada raja", sehingga dapat menjaga rasa saling percaya dalam koalisi penguasa. Dalam kerangka ACF sendiri, kondisi koalisi penguasa yang dominan akan mempermudah proses perubahan kebijakan. Dukungan yang kuat dengan sumber daya simbolik, keuangan, otoritas pengambil keputusan, penguasaan informasi serta kepercayaan yang solid dalam koalisi penguasa mendorong proses penerjemahan janji politik Gubernur DIY menjadi mudah diperjuangkan (Babon et al., 2014).

Kemampuan koalisi penguasa untuk berusaha menjaga kesolidannya dengan sumber daya dan berbagai strategi telah mendorong keberhasilan dalam perjuangan kepentingan. Dinamika yang dihadapi dalam koalisi penguasa juga tidak terlepas dari adanya aktor-aktor yang sempat akan merenggangkan kepercayaan dan perbedaan pandangan terhadap pilihan kebijakan yang diambil. Kerenggangan kepercayaan dalam internal koalisi penguasa dapat diatasi dengan memanfaatkan sumber daya yang dimiliki baik sumber daya simbolik maupun sumber daya legal (Babon et al., 2014). Tiap aktor dalam internal koalisi penguasa didorong untuk tetap fokus memperjuangkan kepentingan pengembangan wilayah selatan DIY untuk perbaikan kesejahteraan sesuai dengan arahan Gubernur DIY. Peran sentral 
Gubernur DIY dalam menjaga kesolidan koalisi penguasa terjadi pada proses awal setelah Sultan HB X menyampaikan janji politiknya. Bappeda DIY didorong untuk "berkompromi" menyesuaikan dengan janji politik yang disampaikan oleh Sultan HB X, meskipun sebelumnya telah membuat rancangan awal secara teknokratik yang telah dipersiapkan. Bappeda DIY sendiri menganggap bahwa janji politik yang disampaikan Sultan HB X lebih visioner dan di luar perkiraan, meskipun mereka sendiri mengakui menghadapi kesulitan dalam menerjemahkan visi-misi yang terkesan filosofis menjadi program kerja (Hasil Wawancara dengan Staf dan Kabid Perencanaan Bappeda DIY pada 26 April 2018).

Peran Gubernur DIY dalam menggerakkan koalisi penguasa juga penting dalam menjaga soliditas di dalam internal pemerintahan sendiri. Arahan dan kepemimpinan Gubernur DIY menjadi sumber daya yang efektif untuk menggerakkan kinerja koalisi penguasa, khususnya pada internal pemerintahan. Tim anggaran menjadi koordinator penyusunan program kerja berdasar pada visi-misi yang disampaikan Gubernur DIY dan memperhatikan tugas dari tiap OPD serta memperhatikan kapasitas fiskal yang ada. Arahan dari Gubernur DIY menjadi penggerak utama kinerja tim anggaran, sehingga penyusunan program kerja di tiap OPD memperhatikan apa yang disampaikan oleh Sultan HB X. OPD bahkan terkesan bergantung pada "instruksi" dari Sultan HB X daripada harus mengambil inisiatif sendiri dalam merumuskan program kerja RPJMD DIY 2017-2022. Arahan Sultan HB X juga berperan untuk memastikan adanya pembelajaran kebijakan yang sama dari setiap OPD, sehingga mencegah terjadinya tumpang tindih penyusunan program (Hasil Wawancara dengan Staf dan Kabid Perencanaan Bappeda DIY pada 26 April 2018). Sultan HB X selaku Gubernur DIY berusaha memastikan tiap bagian dari koalisi penguasa memiliki keyakinan yang sama tentang pilihan kebijakan yang dipilih, sehingga dapat mencegah sikap egosektoral dan tumpang tindih peranan. Hal ini menjadi penting untuk menjaga kesolidan koalisi penguasa dalam mengadvokasikan pilihan kebijakan yang mereka perjuangkan.

Proses kompromi yang diambil Bappeda DIY serta OPD lain pada arahan Sultan HB $\mathrm{X}$ sebagai Gubernur DIY, bila dilihat dengan kacamata ACF dapat ditafsirkan sebagai kondisi di mana para pemangku kepentingan dengan keyakinan yang berbeda berupaya berkomunikasi di antara mereka sendiri dan bagaimana informasi baru berkontribusi pada pembelajaran kebijakan antar pemangku kepentingan. Anggota koalisi mungkin bergantung satu sama lain untuk percaya pada informasi mengenai kepentingan yang ingin mereka perjuangkan daripada anggota koalisi lain. Upaya mewujudkan kesolidan dan rasa percaya antaranggota juga lebih mungkin mengandalkan koordinasi dan menilai strategi terbaik yang akan diterjemahkan ke dalam pilihan program yang diambil (Ainuson, 2009).

Koalisi penguasa menyadari memiliki keterbatasan dalam sumber daya keuangan, sehingga berusaha membangun kerjasama dengan aktor swasta dalam membiayai proyek pembangunan. Aktor swasta menjadi mitra dari koalisi penguasa melalui forum musrenbang maupun forum CSR. Koalisi penguasa melalui Bappeda DIY menyediakan berbagai skema program dan pembiayaan untuk proyek pembangunan yang dianggap menguntungkan bagi investasi pihak aktor swasta. Bappeda DIY bahkan bersedia melakukan sinkronisasi dengan misi perusahaan, agar aktor swasta mau berinvestasi dalam proyek pembangunan yang dikerjakan oleh pemerintah Provinsi DIY (Hasil Wawancara dengan Staf dan Kabid Perencanaan Bappeda DIY pada 26 April 2018). Aktivitas koalisi penguasa dalam kerangka ACF berperan sebagai kendaraan untuk menghubungkan keyakinan dan kepentingan politik menjadi kesepakatan bersama, dan kemudian didapatkanlah keputusan kebijakan. Keyakinan dan kepentingan politik tiap aktor penting 
untuk memengaruhi perilaku, strategi yang diambil koalisi dan beberapa anggota dapat tetap menganut cara advokasi mereka terlepas dari upaya pemerintah memutuskan untuk mengejar pilihan kebijakan lain. Aktor lain seperti pihak swasta dapat ditarik ke dalam koalisi penguasa oleh sumber daya material dan simbolis yang ditawarkan oleh pemerintah, meskipun pilihan kebijakan telah terpilih. Cara pembentukan rasa saling percaya antaraktor dalam koalisi penguasa barangkali didasarkan pada dukungan organisasi dan peran pemimpin politik daripada prinsip-prinsip yang melekat pada ide-ide kebijakan yang akan diperjuangkan (Howlett, Mcconnell, \& Perl, 2016).

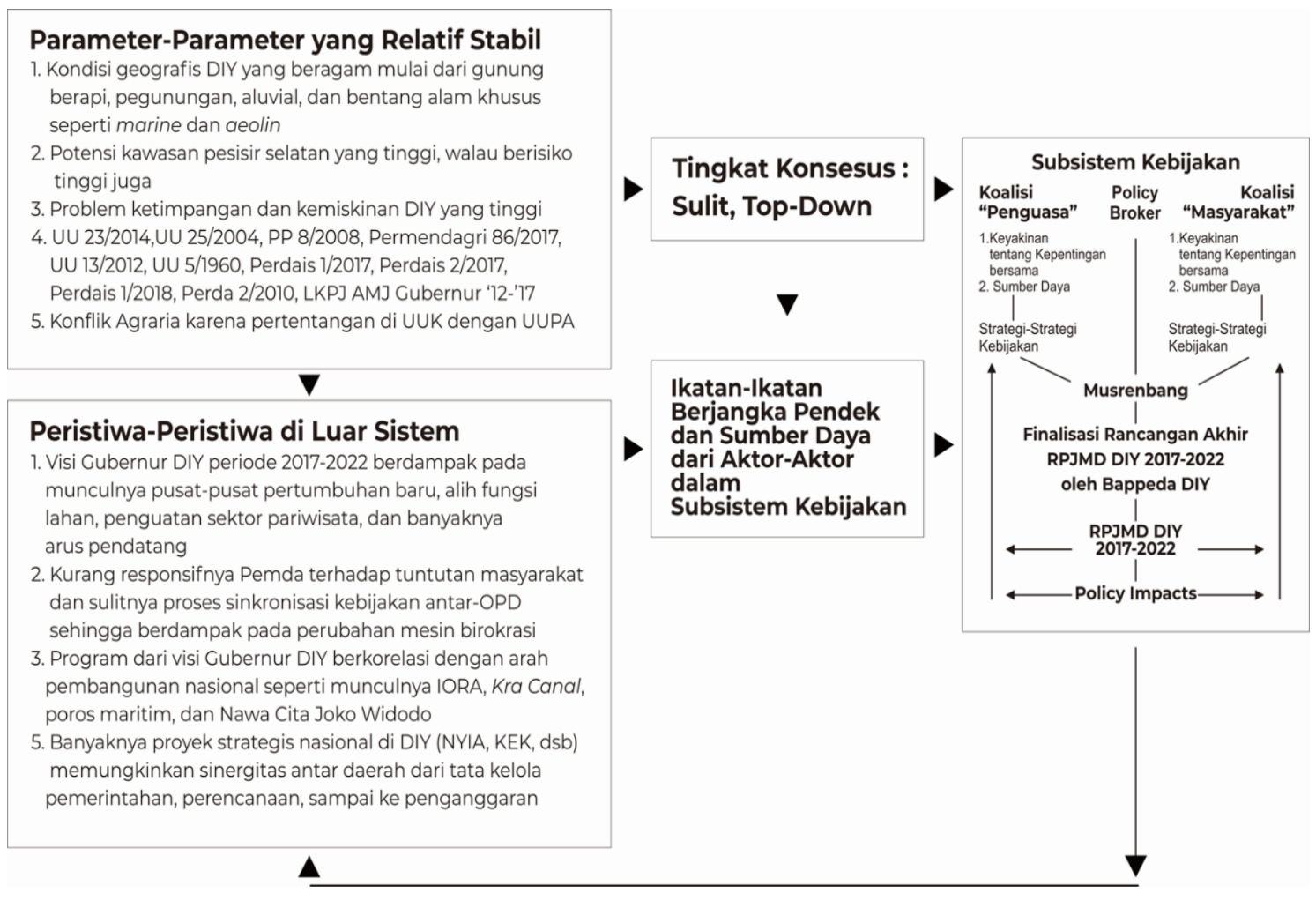

Gambar 1.

Visualisasi Bekerjanya ACF pada Penyusunan Kebijakan RPJMD DIY 2017-2022

Kerangka ACF tidak cukup untuk menjelaskan kompleksitas politik yang muncul dari perumusan kebijakan perencanaan RPJMD DIY 2017-2022. Hal ini disebabkan secara politik, Gubernur DIY memiliki "wajah majemuk", karena peranan yang harus dijalankannya. "Wajah Majemuk" Gubernur DIY itu sendiri terkait peranannya sebagai wakil pemerintah pusat di daerah, kepala daerah otonom yang berstatus otonomi khusus, serta perannya sebagai Sultan Kasultanan Ngayogyakarta Hadiningrat, di mana semua peran ini akan memengaruhi cara dari koalisi penguasa untuk memperjuangkan pilihan kebijakan yang telah dipilih.

Pertama, peran Gubernur DIY sebagai wakil pemerintah pusat di daerah menyebabkan kebijakan perencanaan yang dibuat harus disinkronisasi dengan berbagai urusan pusat yang ada di daerah. Hal ini menyebabkan Gubernur DIY perlu menyinkronkan proyek-proyek pembangunan pemerintah pusat yang ada di daerahnya juga ikut untuk dimasukkan dalam perumusan kebijakan perencanaan. Penyusunan kebijakan perencanaan seperti RPJMD juga tidak terlepas dari pengawasan Menteri Dalam Negeri untuk memastikan pilihan kebijakan yang dipilih telah disinkronisasi dengan kebijakan 
nasional. Regulasi yang ada mendorong setiap proses perencanaan pembangunan untuk dikonsultasikan pada Menteri Dalam Negeri. Hal ini menjadi penting untuk memastikan dukungan daerah terhadap proyek pembangunan pemerintah pusat di tingkat lokal. Interaksi dalam internal koalisi penguasa ini menjadi penting untuk memastikan ada pembelajaran dan pemahaman yang sama mengenai pilihan kebijakan antara pemerintah pusat dan pemerintah daerah. Gubernur DIY dan jajarannya akan mengacu pada indikator yang telah ditetapkan oleh pemerintah pusat dalam merumuskan kebijakan perencanaan seperti RPJMD DIY 2017-2022. Gubernur DIY juga berupaya membangun kompromi dengan mempertimbangkan kapasitas fiskal daerah untuk mencapai target yang ditentukan oleh pemerintah pusat. Kompromi diambil oleh Gubernur DIY dan jajarannya diperlukan untuk memastikan bahwa koalisi penguasa memiliki sumber daya yang memadai untuk memperjuangkan pilihan kebijakan yang dipilih (Hasil wawancara dengan staf dan Kabid Perencanaan Bappeda DIY pada 26 April 2018).

Kedua, Peran Gubenur DIY sebagai kepala daerah otonomi khusus memunculkan konsekuensi kewenangan yang besar dalam menentukan kebijakan perencanaan di daerahnya. Gubernur DIY tidak dipilih melalui pemilihan umum, sehingga setelah dilantik pada masa jabatan baru Sultan HB X dapat langsung menyampaikan pernyataan umum janji politik di hadapan DPRD DIY. RPJMD DIY sendiri merupakan kebijakan yang diusulkan oleh pihak pemerintah daerah kepada DPRD DIY untuk diundangkan bersama menjadi peraturan daerah. Gubernur DIY dan jajarannya bertugas untuk menyampaikan rancangan awal, kemudian akan dibahas bersama dengan DPRD DIY untuk ditetapkan sebagai arah pembangunan lima tahun. Isu yang paling banyak diperdebatkan dalam proses pembahasan RPJMD DIY 2017-2022 adalah mengenai capaian target kemiskinan. Target yang diusulkan oleh Gubernur DIY dianggap terlalu rendah bagi kalangan DPRD DIY, sehingga terjadi tarik-menarik pandangan antara keduanya. DPRD DIY ingin capaian target pengentasan kemiskinan yang lebih tinggi, tetapi pada akhirnya dicapai target kemiskinan sebesar 7\% sebagai bentuk kompromi dengan pihak pemerintah daerah (Hasil wawancara dengan staf ahli Fraksi PAN DPRD DIY pada 17 September 2018).

Terakhir, peran Gubernur sebagai Sultan. Berdasarkan UU No. 13 Tahun 2012, posisi Gubernur dan Wakil Gubernur di Daerah Istimewa Yogyakarta dijabat oleh Sultan Hamengkubuwana dan Sri Paku Alam. Hal ini disebabkan oleh dua hal, yaitu aspek historis Kesultanan Yogyakarta yang menjadi Daerah Istimewa Yogyakarta pasca Maklumat 5 September 1945, yang diratifikasi oleh Pemerintah Indonesia melalui UU No. 3 Tahun 1950 tentang Pembentukan DI Yogyakarta jo. UU No. 22 Tahun 1948. Peraturan ini membuat posisi Sultan Hamengkubuwana X sebagai Gubernur DIY dan Sri Paku Alam sebagai wakil gubernur. Namun, ketika UU No. 32 Tahun 2004 diterbitkan, maka muncul pertanyaan mengenai status Sultan sebagai gubernur. Untuk menyelesaikan hal ini, atas desakan masyarakat yang sudah loyal terhadap gubernur, maka dibuatlah UU No. 13 Tahun 2012 mengenai Keistimewaan DIY yang juga mengatur posisi Sultan sebagai Gubernur (Rachman, 2014). Sultan yang secara kultural sudah terlegitimasi posisinya dalam masyarakat melalui internalisasi nilai-nilai paternalistik berupa kawula-gusti, menjadi lebih kuat posisinya melalui peraturan legal yang ada. Kecenderungan masyarakat Jawa yang lebih mengutamakan kerukunan dan ketundukan pada sistem feodal yang ada menyebabkan jarang adanya perlawanan terhadap posisi Sultan sebagai Gubernur (Hardjowirogo, 1989; Rifayani, Harsasto, \& Martini, 2013; Suseno, 1984).

Isu lain tidak terlalu mengalami perdebatan dalam proses perumusannya, karena kalangan DPRD DIY telah memiliki pemahaman bersama dengan Gubernur DIY mengenai prioritas kerja yang diusulkan. Hanya satu bagian dari kekuatan politik di DPRD 
DIY yang berani mengkritisi isu lain dalam perumusan kebijakan RPJMD DIY 2017-2022 yakni Fraksi Partai Amanat Nasional (PAN). Fraksi PAN berani mengkritisi usulan rancangan RPJMD dari pemerintah yang dianggap tidak sesuai dengan RPJPD DIY. Fraksi PAN juga melihat dari evaluasi pelaksanaan RPJMD DIY 2012-2017 di dalamnya banyak sasaran kegiatan yang tidak tercapai dengan baik. Padahal RPJMD DIY 2012-2017 menjadi titik penting perubahan pembangunan untuk fokus mengembangkan wilayah selatan DIY. Ketidakjelasan parameter yang diusulkan membuat Fraksi PAN DPRD DIY resah dalam usaha memastikan pembangunan terlaksana dengan baik. Akan tetapi, Fraksi PAN hanya bergerak sendiri dan kecenderungan yang muncul dari fraksi partai lain menyetujui usulan yang disampaikan oleh jajaran Gubernur DIY. Kekuatan koalisi penguasa untuk memobilisasi sumber daya simbolik berupa nilai-nilai budaya juga penting untuk menjaga kesolidan dan kemudahan dalam mencapai kompromi untuk membangun pemahaman yang sama terhadap pilihan kebijakan yang diusulkan. (Hasil wawancara dengan staf ahli Fraksi PAN DPRD DIY pada 17 September 2018).

Koalisi masyarakat sipil terkesan bergerak sendiri-sendiri melalui berbagai lembaga swadaya masyarakat (LSM) yang mendampingi. Secara umum, koalisi masyarakat sipil memanfaatkan sumber daya sosial berupa jaringan masyarakat di akar rumput yang didampingi berbagai LSM. Berbagai LSM yang menjadi bagian dari koalisi masyarakat sipil memakai strategi memberikan transfer pengetahuan mengenai perencanaan pembangunan pada warga, agar dapat berpartisipasi dalam merencanakan, mengawal dan mengkritisi pelaksanaan pembangunan. Aktor dapat diagregasikan menjadi koalisi advokasi yang terdiri dari orang-orang dari berbagai organisasi yang berbagi seperangkat keyakinan akan kepentingan bersama. Masing-masing koalisi mengadopsi strategi satu atau lebih dapat berupa inovasi institusional yang dirasakan akan menyukseskan pencapaian tujuan kebijakan yang diperjuangkan (Sabatier, 1988). Hal ini misalnya dilakukan oleh Institute of Research and Empowerment (IRE Yogyakarta) yang berusaha melakukan sinkronisasi dokumen rencana aksi SDGs (Sustainable Development Goals) kepada proses perencanaan pembangunan yang dilakukan oleh pemerintah. Langkah tersebut menjadi bentuk langkah inovatif yang dilakukan oleh koalisi masyarakat sipil untuk memperjuangkan pilihan kebijakan yang akan diusulkan (Hasil wawancara dengan peneliti IRE Yogyakarta pada 18 April 2018).

Aktor lain dari koalisi masyarakat sipil yakni, Perkumpulan IDEA Yogyakarta melakukan usaha memperjuangkan pilihan kebijakan yang berpihak pada masyarakat, dengan berusaha memfasilitasi warga dengan pelatihan. Perkumpulan IDEA Yogyakarta mengajak warga untuk bersama-sama belajar mengenai perencanaan pembangunan dan tata kelola anggaran melalui Focus Group Discussion. Perkumpulan IDEA Yogyakarta mengajak warga untuk memahami pajak yang mereka bayarkan berpengaruh seperti apa bagi kehidupan sehari-hari. Warga mudah mendapatkan kapasitas baru untuk memahami proses perumusan kebijakan, sehingga bisa turut aktif untuk memperjuangkan kepentingannya dalam forum musrenbang. Langkah yang dilakukan oleh Perkumpulan IDEA Yogyakarta meningkatkan sumber daya sosial koalisi masyarakat sipil untuk mencapai keberhasilan dalam memperjuangkan aspirasinya (Hasil wawancara dengan peneliti Perkumpulan IDEA Yogyakarta pada 27 April 2018).

Keberhasilan koalisi pada dasarnya bergantung pada kemampuan mereka untuk menerjemahkan keyakinan ke dalam pilihan kebijakan yang akan diperjuangkan dan kapasitas mereka untuk memprioritaskan dan memobilisasi sumber daya untuk membuat perubahan kebijakan. Koalisi menggunakan informasi teknis dalam mengembangkan agenda kebijakan mereka. Keyakinan akan adanya kepentingan bersama adalah faktor 
pemersatu koalisi. Keyakinan ini menjadi filter untuk menentukan mana informasi teknis yang cocok dipilih dan mudah dipahami. Karena itu, proses transfer pengetahuan baru diperoleh melalui pembelajaran yang dibingkai oleh keyakinan akan kepentingan bersama. Informasi yang berkontribusi pada pembelajaran tidak diperkenalkan berasal dari luar, tetapi dari dalam koalisi, dan itu menjadi sumber daya strategis yang digunakan untuk membangun dan menumbuhkan koalisi, serta meyakinkan pembuat keputusan untuk mendukung tujuan, dan memengaruhi opini publik (Clark, 2018).

Kepentingan antara koalisi penguasa dan koalisi masyarakat sipil yang berbeda perlu dipertemukan, agar pilihan kebijakan yang diambil benar-benar mencerminkan kebutuhan tiap pihak. Strategi yang bertentangan dari berbagai koalisi biasanya dimediasi oleh kelompok aktor ketiga, yakni policy broker untuk menemukan kompromi yang masuk akal, demi mengurangi intensitas konflik antar koalisi. Hasil akhirnya adalah satu atau lebih program pemerintah berupa output kebijakan di tingkat operasional (Sabatier, 1988). Akan tetapi, biasannya proses consensus building yang akan digagas oleh policy broker belum tentu dapat mempertemukan kepentingan dari tiap koalisi. Dalam perumusan kebijakan RPJMD DIY 2017-2022, Bappeda DIY bertindak sebagai policy broker dengan memfasilitasi partisipasi koalisi masyarakat sipil melalui forum musrenbang. Forum musrenbang menjadi upaya untuk memastikan adanya usulan kebijakan dari masyarakat. Dalam kacamata ACF, musrenbang menjadi jalan ketiga bagi perubahan kebijakan yang melibatkan interaksi policy subsystem secara aktif dengan kesempatan menyampaikan usulan kebijakan yang dianggap relatif sama (Weible, Sabatier, \& Mcqueen, 2009).

Koalisi masyarakat sipil melihat musrenbang tidak cukup memadai untuk mengakomodasi aspirasi dari warga. Musrenbang memiliki kelemahan pada keterbatasan waktu yang disediakan, proses penyampaian pilihan kebijakan yang terkesan satu arah serta minimnya variasi forum tematik yang disediakan. Musrenbang hanya terkesan menjadi langkah yang bersifat formalitas yang diambil koalisi penguasa untuk "memuluskan" pilihan kebijakan yang mereka perjuangkan (Hasil wawancara dengan peneliti Perkumpulan IDEA Yogyakarta pada 27 April 2018). Kalangan lain dari koalisi masyarakat sipil, yakni Wahana Lingkungan Hidup (Walhi) Yogyakarta melihat bahwa musrenbang hanya terkesan sebagai forum konsultasi publik terhadap rancangan perencanaan pembangunan yang telah dibuat oleh pemerintah. Forum musrenbang tidak memungkinkan bagi koalisi masyarakat sipil untuk mengintervensi rancangan yang telah dibuat oleh pihak pemerintah. Musrenbang hanya menjadi sarana bagi pemerintah untuk meminta persetujuan serta respon warga terhadap rancangan kebijakan yang telah dibuat (Hasil wawancara dengan aktivis Walhi Yogyakarta 12 September 2018).

Bappeda DIY berusaha menengahi dengan memutuskan melihat berbagai kepentingan dari masing-masing koalisi dan diterjemahkan sebagai rancangan akhir RPJMD DIY 2017-2022. Bappeda DIY menengahi tarik-menarik kepentingan antar koalisi dengan menentukan prioritas kerja menjadi empat isu strategis yang harus diselesaikan dalam lima tahun mendatang, yakni isu kemiskinan, ketimpangan wilayah, sarana penunjang Bandara NYIA, serta mekanisme pembiayaan di luar APBD. Pentingnya peran policy broker yang bertindak sebagai mediator atau perantara politik yang bertugas menemukan kompromi yang dapat diterima tiap koalisi dan membatasi konflik antar koalisi. Dua faktor yang terutama bertanggung jawab dalam pembentukan konsensus antar koalisi adalah pembelajaran kebijakan berorientasi dalam subsistem kebijakan dan faktor pendorong eksternal yang dapat memengaruhi distribusi sumber daya para aktor (Khayatzadeh-mahani et al., 2018). 
Pembelajaran kebijakan dapat memimpin koalisi untuk memperbaiki dan menyesuaikan sistem keyakinannya untuk mencapai tujuannya secara lebih efisien, pada gilirannya memengaruhi persepsi masalah dan solusi yang diusulkan di antara anggota koalisi. Jalur kompromi yang ditempuh melalui peran Bappeda DIY sebagai penengah tarik-menarik kepentingan antara koalisi penguasa dan koalisi masyarakat sipil penting untuk memastikan perubahan kebijakan dapat diwujudkan. Pembentukan konsensus melalui peran policy broker yang berasal dari kalangan pemerintahan telah memaksa koalisi masyarakat sipil mengambil pembelajaran kebijakan dengan "mengalah". Koalisi masyarakat sipil tetap mencoba mencari saluran lain serta tetap mengawal perubahan kebijakan yang diambil untuk mengimbangi dominasi kalangan penguasa (Khayatzadehmahani et al., 2018).

Pola pembentukan konsensus pada perumusan kebijakan RPJMD DIY 2017-2022 berlangsung melalui jalur keempat dari skema ACF yakni, "forum profesional" yang memberikan pengaturan kelembagaan yang memungkinkan koalisi untuk bernegosiasi, menyetujui, dan menerapkan perjanjian secara aman. Jalur pertama (faktor eksternal yang dinamis seperti perubahan kondisi sosial-ekonomi DIY, perubahan opini publik tentang kinerja pemerintah, dll), jalur kedua (proses pembelajaran yang berorientasi pada kebijakan), serta jalur ketiga perubahan kebijakan (kondisi tarik-menarik kepentingan antar koalisi) dalam kerangka ACF tampaknya tidak berhasil digunakan untuk melakukan consensus building dalam perumusan kebijakan RPJMD DIY 2017-2022. Sesuai dengan paparan Weible dan Sabatier (2009) telah mengidentifikasi sembilan kondisi yang memengaruhi kemungkinan kebijakan berubah melalui jalur keempat ini, yakni: kebuntuan dalam mempertemukan kepentingan antar koalisi, kepemimpinan yang efektif, konsensus berdasarkan aturan, pendanaan beragam, durasi proses dan komitmen anggota, fokus pada isu-isu empiris, penekanan pada membangun kepercayaan, dan kurangnya saluran alternatif untuk berinteraksi (Weible et al., 2009).

\section{E. PENUTUP}

Dari penelitian ini, ditemukan juga bahwa dalam model ACF ini terdapat beberapa kekurangan. Kekurangan pertama berkaitan dengan ketidakmampuan ACF untuk menjelaskan posisi salah satu pihak yang "berwajah majemuk". Di mana dalam kasus ini adalah Sultan itu sendiri. Kekurangan berikutnya adalah ACF tidak dapat menjelaskan dengan detail alasan terbentuknya sebuah koalisi secara pasti. Di mana dalam kasus ini pembentuk koalisi antara satu koalisi dengan yang lain berbeda jauh. Kekurangan terakhir yaitu ACF tidak dapat menjelaskan terpencarnya gerakan dalam suatu koalisi. Di sini terlihat dari berbedanya arah gerak dari tiap "anggota" koalisi masyarakat sipil.

Dari penelitian ini, peneliti menyarankan kepada pihak Pemerintah untuk menjalankan proses perencanaan terpadu, sehingga antara Bappeda dengan Gubernur tidak terjadi perbedaan rencana sehingga proses perencanaan bisa lebih efektif. Selain itu, untuk memaksimalkan partisipasi warga, pemerintah bisa membuat semacam Forum Warga yang lebih banyak melibatkan warga (di mana warga menjadi pengusul utama, bukan pemerintah), sehingga dapat menghindari praktik "sosialisasi" dan pemosisian warga sebagai objek yang sering terjadi dalam musrenbang. Kemudian, untuk masalah penyusunan Rencana Tata Ruang Wilayah yang hingga sekarang belum selesai, pemerintah bisa melakukan sinkronisasi terlebih dahulu terhadap seluruh perencanaan tata ruang yang ada. Selain itu, perbaikan pengawasan dalam pemberian izin, pengaktifan kembali BPN, dan penggunaan forum warga yang lebih menjadikan warga sebagai "subjek". 


\section{DAFTAR PUSTAKA}

Afriko, M. (2013). Panduan Pendampingan Perencanaan Pembangunan Daerah Pembelajaran dari Metode Pendampingan Penyusunan RPJMD Kabupaten Bener Meriah oleh Forum Peneliti Aceh. (M. Afriko, Ed.). Banda Aceh: Kerjasama Consolidating Peaceful Development in Aceh (CPDA), Forum Peneliti Aceh (FPA), Pemerintah Kabupaten Bener Meriah.

Ainuson, K. (2009). An advocacy coalition approach to water policy change in Ghana: A look at belief systems and policy oriented learning. Journal of African Studies and Development, 1(2), 16-27.

Babon, A., Mcintyre, D., Gowae, G. Y., Gallemore, C., Carmenta, R., \& Gregorio, M. Di. (2014). Advocacy coalitions, REDD + , and forest governance in Papua New Guinea : how likely is transformational change? Ecology and Society, 19(3).

Esa, Radin Fadhillah. (2016). Pertarungan Kepentingan Politik dalam Perumusan RPJM Daerah Kabupaten Mojokerto Tahun 2011-2015. Jurnal Politik Muda, Vol. 5, No. 2 , hlm. 256-267.

Cahyadi, A., Afianita, I., Gamayanti, P., \& Fauziyah, S. (2012). Evaluasi Tata Ruang Pesisir Sadeng Gunungkidul (Perspektif Pengurangan Risiko Bencana). In Seminar Nasional SCAN (Sustainable, Culture, Architecture and Nature) Ke-3 (pp. 1-8). Yogyakarta: Prodi Arsitektur Jurusan Teknik Universitas Atma Jaya Yogyakarta.

Clark, J. K. (2018). From civic group to advocacy coalition : Using a food policy audit as a tool for change. Journal of Agriculture, Food Systems, and Community Development, $\underline{8(1), 21-38 .}$

Deni. (2017). Visi misi Gubernur DIY harus bisa lebih operasional. Retrieved September 10, 2018, from http://www.starjogja.com/2017/11/22/visi-misi-gubernur-diy-harusbisa-lebih-operasional/

Gubernur Daerah Istimewa Yogyakarta. (2017). Laporan Keterangan Pertanggungjawaban Akhir Masa Jabatan Tahun 2012-2017 Gubernur Daerah Istimewa Yogyakarta. Yogyakarta.

Hardjowirogo, M. (1989). Manusia Jawa. Jakarta: Haji Masagung.

Hasim, R. A. (2016). Politik Hukum Pengaturan Sultan Ground dalam Undang-Undang No. 13 Tahun 2013 Tentang Keistimewaan Yogyakarta dan Hukum Tanah Nasional. Arena Hukum, 9(2), 207-224.

Hastuti, A. W. (2012). Analisis Kerentanan Pesisir Terhadap Ancaman Kenaikan Muka Laut di Selatan Yogyakarta. Institut Pertanian Bogor.

Howlett, M., Mcconnell, A., \& Perl, A. (2016). Moving Policy Theory Forward: Connecting Multiple Stream and Advocacy Coalition Frameworks to Policy Cycle Models of Analysis Introduction: Policy Process. Australian Journal of Public Administration, 00(0), 1-15. https://doi.org/10.1111/1467-8500.12191

Iskandar, A. (2012). Peranan badan perencanaan pembangunan daerah dalam penyusunan kebijaksanaan dibidang pembangunan di kabupaten tanggamus. Keadilan Progresif, 3(12), 22-36.

Jenkin-Smith, H. C., \& Sabatier, P. A. (1994). Evaluating the Advocacy Coalition Framework. Journal of Public Policy, 14(2), 175-203.

Khayatzadeh-mahani, A., Breton, E., Ruckert, A., \& Labonte, R. (2018). Banning shisha smoking in public places in Iran: an advocacy coalition framework perspective on 
policy process and change. Health Policy and Planning, 32(March 2017), 835-846. https://doi.org/10.1093/heapol/czx015

Kulac, O., \& Ozgur, H. (2017). An Overview of the Stages (Heuristics) Model as a Public Policy Analysis Framework. European Scientific Journal, Special, 114-157.

Mustafa, M. A., \& Yudichara. (2007). Karakteristik Pantai dan Resiko Tsunami di Kawasan Pantai Selatan Yogyakarta. Jurnal Geologi Kelautan, 5(3), 159-167.

Nadjib, A. (2017). Angka Kemiskinan DIY Tertinggi se-Jawa. Retrieved November 12 , 2018, from sindonews.com: https://daerah.sindonews.com/read/1226314/189/angkakemiskinan-diy-tertinggi-se-jawa-1501649326

Nursini. (2010). Perencanaan Pembangunan Dan Penganggaran Daerah Teori Dan $\begin{array}{lllll}\text { Aplikasi. } & \text { Retrieved } & \text { February } & 2, & \text { 2018, }\end{array}$ https://core.ac.uk/download/pdf/77629914.pdf

Padang, W.S, Kusmanto, H. (2015). Perencanaan Partisipatif dalam Proses Penyusunan Rencana Pembangunan Jangka Menengah Daerah Kabupaten Dairi Tahun 2014-2019. Jurnal Administrasi Publik, Vol. 5 No. 2, hlm. 195-216.

Paripurna, E. T., Nugroho, A. B., Wicaksono, A. P., Pradhana, G., \& Nugroho, N. E. (2015). Kajian Peningkatan Risiko Bencana Tsunami di Pantai Selatan Kulon Progo: Studi Kasus pada Rencana Tapak Pembangunan Bandara Kulon Progo. In Simposium Nasional Mitigasi Bencana Tsunami (pp. 1-7). Banda Aceh: UPT Mitigasi Bencana Universitas Syiah Kuala.

Pemerintah Daerah Istimewa Yogyakarta. (2018). Peraturan Daerah Daerah Istimewa Yogyakarta Nomor 3 Tahun 2018 Tentang Rencanan Pembangunan Jangka Menengah Daerah Daerah Istimewa Yogyakarta Tahun 2017-2022. Yogyakarta: Pemerintah Daerah Istimewa Yogyakarta.

Prihatin, R. B. (2016). Alih Fungsi Lahan di Perkotaan (Studi Kasus di Kota Bandung dan Yogyakarta). Jurnal Aspirasi (Trial), 6(2), 105-118.

Purnama, Eddy (2013). Tata Cara Penyusunan Rencana Pembangunan Daerah Kabupaten/Kota di Aceh, Kanun Jurnal Ilmu Hukum, No. 59, Th. XV, hlm. 1-26.

Puspita, R. I. (2016). Analisis Penyusunan Agenda Kebijakan Publik (Studi Kajian Agenda Penyusunan Kebijakan Penyelesaian Pelanggaran RTRW Oleh Industri CV. Evergreen Indogarment). Universitas Diponegoro.

Rachman, A. A. (2014). Dinamika Kerukunan Umat Beragama dalam Kepemimpinan Kesultanan Yogyakarta. Akademika, 9(1), 90-116.

Rifayani, S. D., Harsasto, P., \& Martini, R. (2013). Implikasi Kedudukan Gubernur Daerah Istimewa Yogyakarta terhadap Demokratisasi dan Efektivitas Pemerintahan Daerah Istimewa Yogyakarta. Jurnal Ilmu Pemerintahan, 1-10.

Sabatier, P. A. (1988). An Advocacy Coalition Framework of Policy Change and the Role of Policy-Oriented Learning Therein. Policy Sciences, 21(2/3), 129-168.

Sahubawa, L., Khakim, N., \& Lasindrang, M. (2015). Kajian Sebaran Potensi Ekonomi Sumber Daya Kelautan di Pantai Selatan Daerah Istimewa Yogyakarta sebagai Upaya Percepatan Investasi. Jurnal Teknosains, 4(2), 101-120.

Soares, A., Nurpratiwi, R., \& Makmur, M. (2015). Peranan Pemerintah Daerah Dalam Perencanaan Pembangunan Daerah. JISIP: Jurnal Ilmu Sosial Dan Ilmu Politik, 4(2), 231-236.

Somad, A. (2016). Gerakan Petani Kulon Progo Melawan SG dan PAG. Retrieved November 12, 2018, from indoprogress.com: https://indoprogress.com/2016/10/gerakan-petani-Kulon Progo-melawan-sg-dan-pag/ Suseno, F.-M. (1984). Etika Jawa: Sebuah Analisa Falsafi tentang Kebijaksanaan Hidup 
Jawa. Jakarta: Penerbit PT Gramedia.

Syaifullah. (2007). Analisis Perencanaan Pembangunan Tahunan Daerah Di Kota Magelang (Studi Kasus Perencanaan Pembangunan Tahun 2007). Universitas Diponegoro.

Tompo, G. Z., Kadir, A. G., \& Mufhi, A. (2012). Analisis Peranan Bappeda dalam Pembangunan di Kabupaten Jeneponto. Government: Jurnal Ilmu Pemerintahan, 5(1), 9-20.

Wedhaswary, I. D. (2014). Nawa Cita Jokowi-Jusuf Kalla. Retrieved November 10, 2018, from

https://nasional.kompas.com/read/2014/05/21/0754454/.Nawa.Cita.9.Agenda.Prioritas Jokowi-JK

Weible, C. M., \& Sabatier, P. A. (2007). A Guide to the Advocacy Coalition Framework. In F. Fischer, G. J. Miller, \& M. S. Sidney (Eds.), Handbook of Public Policy Analysis: Theory, Politics, and Methods (pp. 123-136). New York: CRC Press Taylor \& Francis Group.

Weible, C. M., Sabatier, P. A., \& Mcqueen, K. (2009). Themes and Variations: Taking Stock of the Advocacy Coalition Framework, 37(1).

Yudhicara, Yuningsih, A., Mustafa, A., Kristanto, N., \& Noviadi, Y. (2003). Potensi Kebencanaan Geologi di Kawasan Pesisir Selatan DI Yogyakarta. Jurnal Geologi Kelautan, 1(1), 9-14.

Yuliadi, I. (2013). South Coastal Community Development: Issues and Challenges. Jurnal Ekonomi Pembangunan, 14(2), 172-179. 